\title{
Bralni test v 3. razredu na OŠ Loka Črnomelj
} Ana Gorše

\begin{abstract}
Uvod
Namen mojega prispevka je predstaviti 5-letno izkušnjo izvajanja Bralnega testa na Osnovni šoli Loka Črnomelj. Z načrtnim procesom opismenjevanja se učenci srečajo že takoj ob vstopu v šolo in ena osrednjih učnih dejavnosti v tem obdobju je razvoj temeljnih bralnih spretnosti in zmožnosti - tj. usvajanje in avtomatizacija tehnike branja ter razvoj bralnega razumevanja.
\end{abstract}

Tudi naš učni načrt glede razvoja bralnih sposobnosti poudarja, da razvita bralna zmožnost, tj. hitro/avtomatizirano branje $\mathrm{z}$ razumevanjem, predstavlja osrednjo učno spretnost, od katere je v veliki meri odvisna tudi nadaljnja učna, s tem pa tudi izobrazbena in poklicna pot posameznika (Učni načrt za slovenščino, 2018). To pa vedno znova potrjujejo tuje in domače študije (Bryant in Nunes, 2004; Goswami in Bryant, 1990; Pečjak 2010; Verhoeven in Snow, 2001). Hkrati pa raziskave kažejo, da zaostanki v tehniki in avtomatizaciji branja, ki nastanejo v prvem triletju, pozneje ostajajo in ti učenci med izobraževanjem nikoli ne dohitijo vrstnikov (Magajna, Gradišar, Mesarič, Pečjak in Pust, 1999). Zato je spremljanje razvoja bralnih zmožnosti učencev v prvih treh letih šolanja ena glavnih dejavnosti učitelja in tudi svetovalnih delavcev.

Mednarodne raziskave bralne pismenosti kažejo, da imajo naši 1o-letni učenci (učenci $v$ 4. razredu) slabšo bralno pismenost kot njihovi vrstniki v razvitih, $\mathrm{z}$ nami primerljivih državah sveta (PIRLS, 2011). Ob tem 
spremljevalne študije bralnih dosežkov učencev kažejo, da k dobri bralni pismenosti vodita dve »orodji«, in sicer prvo je avtomatizirana tehnika branja (ki se kaže kot tekoče in sproščeno branje), druga pa je obvladanje različnih bralni strategij, ki jih učenec uporablja pri predelavi besedila.

Spremljanje razvoja bralnih zmožnosti je pomembno zaradi več razlogov: 1) učitelju nudi povratno informacijo, kako in koliko učenci dosegajo z učnim načrtom zastavljene cilje; 2) učitelju pomaga odkrivati močne in šibke točke učencev v razvoju te zmožnosti, kar je zlasti pomembno ob pojavljanju težav pri branju. To namreč 3 ) nudi izhodišče za učinkovito intervencijo - tako omogoča učitelju učinkovitejše poučevanje in prilagajanje dela učencu $v$ okviru rednega pouka, dopolnilnega pouka in/ali individualnega dela $\mathrm{z}$ učencem; hkrati pa mu pomaga tudi pri presoji, kdaj učenca napotiti $\mathrm{k}$ svetovalnemu delavcu ali pa $\mathrm{v}$ ustrezne specializirane ustanove (Pečjak, Magajna, Podlesek, 2012).

Pri svojem raziskovanju sem ugotovila, da rezultati bralnega testa hitro pokažejo, kateri učenci ob koncu tretjega razreda osnovne šole še niso $\mathrm{v}$ zadostni meri razvili tehnike branja in bralnega razumevanja. To jih uvršča v skupino učencev, ki potrebujejo dodatno diagnostiko oz. obravnavo. S predstavitvijo primera želim spodbuditi čim več učiteljev, svetovalnih delavcev $\mathrm{k}$ uporabi testa, zato se $\mathrm{v}$ nadaljevanju osredotočam na praktične napotke pri izvedbi testa. Dodala sem možne izboljšave pri izvedbi testiranja.

Za izvedbo testiranja sem uporabila bralni test avtoric dr. Sonje Pečjak in dr. Nataše Potočnik. Gre za presejalni test, ki je predviden za uporabo na celotni populaciji učencev. Njegov namen je zbiranje podatkov z namenom identifikacije učencev, ki potrebujejo dodatne, bolj intenzivne oblike ocenjevanja. Test mora biti učinkovit, hiter in zanesljiv. Predvsem pa je pomembno, da presejalni testi odkrijejo vse učence, ki so rizični za pojav težav pri učenju, ki jih ugotavljajo (Magajna, 2011). Testirala sem torej vse učence tretješolce ( $v$ skupini so bili učenci s posebnimi potrebami, učenci z učnimi težavami, Romi, tujci) na OŠ Loka Črnomelj ter na podružnični šoli Griblje in Adlešiči.

Test ugotavlja splošno bralno zmožnost učencev ob zaključku tretjega razreda. Je standardiziran merski instrument, s katerim izmerimo, do kakšne stopnje so razvite osnovne bralne zmožnosti pri učencih. Uporabljajo ga lahko učitelji in svetovalni delavci, pred uporabo pa je potrebno opraviti usposabljanje. Bralni test je sestavljen iz dveh podtestov, in sicer Hitrost razumevanje in Stopnja razumevanja. Pridobljene informacije nam služijo predvsem za načrtovanje nadaljnjega dela na področju bralne pi- 
smenosti. Ugotovljeno stanje nudi izhodišče za pomoč učencem v okviru petstopenjskega modela obravnave učencev z učnimi težavami (Pečjak, Magajna, Podlesek, 2011).

\section{Uporabljena metodologija}

Test sestavljajo: Knjižica z bralnimi nalogami, Odgovorni list, Šablona, Grafični prikaz rezultatov.

Knjižica $\mathrm{z}$ bralnimi nalogami vsebuje dva podtesta:

- Podtest Hitrost razumevanja nam pove, kakšna hitrost branja učencu še omogoča razumevanje. Test je sestavljen iz nalog izbirnega tipa. Vsebuje povedi, ki jih je potrebno dopolniti z eno besedo. Učenci izberejo ustrezno besedo izmed petih ponujenih. Reševanje traja 7 minut in pol.

- Podtest Stopnja razumevanja nam pove stopnjo razumevanja prebranega pri posameznem učencu. Test vsebuje več krajših besedil, ki vsebujejo približno 5 povedi. Besedilu sledijo vprašanja izbirnega tipa, učenci izberejo ustrezen odgovor izmed petih možnosti. Reševanje traja 10 minut (Pečjak, Magajna, Podlesek, 2011).

Učenci odgovore obkrožijo na odgovornem listu. Knjižice z nalogami lahko tako večkrat uporabljamo, odgovore na listu pregledamo zelo hitro in enostavno s pomočjo šablone za vrednotenje rezultatov.

V testiranje so od šolskega leta 2014/15 vključeni vsi tretješolci matične šole ter podružnične šole Adlešiči in Griblje. Testiranje se izvaja konec maja oz. v začetku junija, vedno 1. šolsko uro pouka.

\section{Rezultati in ugotovitve}

Ob izvajanju testa ugotavljam, da je v nekaterih oddelkih potrebno večkrat ponoviti navodila za reševanje in pri učencih tudi preveriti, ali so jih razumeli. A to se razlikuje od posamezne generacije, zato ne gre posploševati. Učenci so imeli veliko težav z odgovarjanjem na Odgovorne liste, saj je nanje potrebno pravilne odgovore zgolj obkrožiti. Učenci so se motili s tem, da so pravilne odgovore obkroževali v knjižice z nalogami.

Po prvem delu testa smo naredili nekaj sprostitvenih vaj, saj je drugi del predstavljal težji izziv. Ker je izhodiščno besedilo daljše, so nekateri učenci (učenci s posebnimi potrebami, učenci Romi - učenci, za katere so 
mi po testiranju povedale razredničarke, da njihovo branje še ni avtomatizirano) obupali in prenehali z reševanjem ali so celo naključno obkroževali odgovore.

Po končanem delu $\mathrm{z}$ učenci (traja $45 \mathrm{~min}$ ) sem rezultate pregledala. Uporabila sem šablono in za pregled testov enega razreda in grafično predstavitev rezultatov potrebovala približno pol ure. Za vsak razred sem pripravila grafični prikaz rezultatov učencev. Rezultat na podtestu Hitrost razumevanja je označen s simbolom \#, rezultat na podtestu Stopnja razumevanja pa s simbolom $o$.

Tabela za grafični prikaz je razdeljena na tri območja:

- $\quad$ nadpovprečen rezultat (75-100 percentil),

- povprečen rezultat (25-75 percentil),

- podpovprečen rezultat (o-25 precentil).

Učiteljem predstavim rezultate posameznega učenca in opažanja ob reševanju testa, posebno o vedenju med preizkusom in motivaciji učencev za reševanje. Nekaj učencev v 3. razredu bere potiho tako, da premika ustnice, ali bere šepetaje. Vse to vpliva na hitrost branja, zato je to potrebno čim prej odpraviti. Učiteljem razrednikom izpostavim učence, ki so na enem ali obeh podtestih dosegli podpovprečen rezultat. Večinoma rezultati niso presenečenje, saj učitelj odkrije učenca $z$ bralnimi težavami že pred testiranjem kakor tudi učence, ki dosežejo nadpovprečne rezultate. Nato pa predstavimo še staršem, da ima otrok težave in potrebuje dodatno pomoč na področju branja. Načrt pomoči naredimo ob pomoči šolske svetovalne službe. $\mathrm{V}$ individualizirani načrt vključimo konkretne napotke, da učenec premaga bralne težave. Nekaj nasvetov lahko najdemo v knjigi Sonje Pečjak z naslovom Kako do boljšega branja, Zavod RS za šolstvo in šport, Ljubljana (1993). Opažam, da se v vsaj kakšnem oddelku na leto najde učenec, ki vpraša (kar med testiranjem) za razlago posamezne besede. Ko se na koncu testiranja pogovorim z vsemi učenci, ali so to besedo razumeli, je po navadi odgovor negativen. To kaže na slabše razumevanje besedišča, kar lahko uspešno vadimo z vajami iz knjige Zrno do zrna pogača (Vaje za spoznavanje pomena besed in bogatenje besedišča), avtoric Jadranke Zupan in Daše Pelikan - Prek (Zavod RS za šolstvo, Ljubljana 1997). 
Tabela 47: Število testiranih tretješolcev OŠ Loka Črnomelj (N) po posameznih letih glede na podtest (Hitrost razumevanja in Stopnja razumevanja) ter rezultati (številčno in v odstotkih) po posameznih območjih (nadpovprečen, povprečen, podpovprečen rezultat).

\begin{tabular}{|c|c|c|c|c|c|c|c|}
\hline \multirow[b]{2}{*}{ Šolsko leto } & \multirow{2}{*}{$\begin{array}{l}\mathrm{N} \\
\text { (število testiranih } \\
\text { tretješolcev na OŠ } \\
\text { Loka Črnomelj, PŠ } \\
\text { Adlešiči, PŠ Gri- } \\
\text { blje) }\end{array}$} & \multicolumn{3}{|c|}{ Hitrost razumevanja (\#) } & \multicolumn{3}{|c|}{ Stopnja razumevanja $(o)$} \\
\hline & & $\begin{array}{l}75-100 \\
\text { percen- } \\
\text { til }\end{array}$ & $\begin{array}{c}25-75 \\
\text { percen- } \\
\text { til }\end{array}$ & $\begin{array}{c}0-25 \\
\text { precen- } \\
\text { til }\end{array}$ & $\begin{array}{l}75-100 \\
\text { percen- } \\
\text { til }\end{array}$ & $\begin{array}{c}25-75 \\
\text { percen- } \\
\text { til }\end{array}$ & $\begin{array}{c}0-25 \\
\text { precen- } \\
\text { til }\end{array}$ \\
\hline $2014 / 15$ & 59 & $25(42 \%)$ & $24(41 \%)$ & $10(17 \%)$ & $14(24 \%)$ & $27(46 \%)$ & $18(30 \%)$ \\
\hline $2015 / 16$ & 74 & $26(35 \%)$ & $28(38 \%)$ & $20(27 \%)$ & $17(23 \%)$ & $25(34 \%)$ & $32(43 \%)$ \\
\hline $2016 / 17$ & $\begin{array}{l}\text { Testiranje ni bilo } \\
\text { izvedeno zaradi } \\
\text { porodniške odsot- } \\
\text { nosti izvajalke. }\end{array}$ & l & l & l & l & l & l \\
\hline $2017 / 18$ & 55 & $17(31 \%)$ & $18(33 \%)$ & $20(36 \%)$ & $7(13 \%)$ & $23(42 \%)$ & $25(45 \%)$ \\
\hline $2018 / 19$ & 53 & $10(19 \%)$ & $26(49 \%)$ & $17(32 \%)$ & $6(11 \%)$ & $15(28 \%)$ & $32(61 \%)$ \\
\hline $2019 / 20$ & 58 & $23(40 \%)$ & $25(43 \%)$ & $10(17 \%)$ & $14(24 \%)$ & $19(33 \%)$ & $25(43 \%)$ \\
\hline
\end{tabular}

Tabela 47 prikazuje podatke od šolskega leta 2014/15 do šolskega leta 2019/20. Velikost vzorca variira od vpisa učencev, a v petih letih je povprečno na OŠ Loka Črnomelj s podružničnima šolama 60 tretješolcev. Testiramo vedno vse tretješolce, kar učenci vedo vnaprej. Testiranje opravimo konec šolskega leta - konec meseca maja ali v začetku junija. Razredničarka učencem pove, da pride 1. šolsko uro učiteljica, ki bo izvedla Bralni test. Starši pa to izvedo na 1. roditeljskem sestanku v začetku šolskega leta 3. razreda.

Tabela prikazuje, koliko učencev se je na posameznem podtestu uvrstilo v zgornjih $25 \% \mathrm{v}$ skupini vrstnikov (so dosegli nadpovprečni rezultat) oz. v spodnjih $25 \%$ v skupini vrstnikov (ti so dosegli podpovprečen rezultat) ali pa se njihovi rezultati ujemajo $\mathrm{z}$ doseženim povprečjem $\mathrm{v}$ skupini svojih učencev.

Naši učenci so na testu Hitrost razumevanja v šolskem letu 2014/15 in 2019/20 dosegli najboljše rezultate - v teh letih je največ učencev med $25 \%$ najboljših v skupini vrstnikov in najmanj jih je med $25 \%$ najslabših v skupini vrstnikov. Pri testu Stopnja razumevanja so letošnji rezultati sicer veliko boljši od rezultatov iz leta 2018/19, a so bili v šolskem letu 2014/15 še boljši. Enak odstotek ( $24 \%$ ) učencev je med boljšimi $25 \%$ v skupini vrstnikov, tako v šolskem letu 2014/15 kakor tudi 2019/20. Pri učencih, uvrščenih v spodnjo sivino (ki so dosegli rezultate primerljive s $25 \%$ slabših v skupini vrstnikov), pa je bilo v šolskem letu 2014/15 uvrščenih najmanj učencev, 
največ pa v šolskem letu 2018/19 (kar $61 \%$ ). Učencev, ki se na testu Stopnja razumevanja po rezultatih uvrščajo v samo povprečje (srednje, belo območje, gl. Tabelo 47), je bilo v šolskem letu 2014/15 največ (kar $46 \%$ ), najmanj pa v šolskem letu 2018/19 (28\%).

Za lažji pregled prilagam Tabelo 48, kjer je individualni rezultat za 9 učencev in se razločneje vidi, kaj pomeni zgornjih/spodnjih $25 \%$; v Tabeli 48 je zaznati spodnjo/zgornjo sivino.

\section{Tabela 48: Rezultati Bralnega testa posameznih učencev istega razreda}

\begin{tabular}{|c|c|c|c|c|c|c|c|c|c|c|c|c|}
\hline \multicolumn{3}{|c|}{$\begin{array}{c}\text { HITROST } \\
\text { RAZUMEVA- } \\
\text { NJA }\end{array}$} & \multicolumn{8}{|c|}{$\begin{array}{l}\text { RAZRED: } 3 \cdot \text { (9 naključnih rezultatov učencev) } \\
\text { UČENEC }\end{array}$} & \multicolumn{2}{|c|}{$\begin{array}{c}\text { STOPNJA } \\
\text { RAZUMEVANJA } \\
0\end{array}$} \\
\hline $\begin{array}{c}\% \\
\text { Slabših } \\
\text { bralcev }\end{array}$ & $\begin{array}{l}\text { Števi- } \\
\text { lo PRA- } \\
\text { VILNO } \\
\text { rešenih }\end{array}$ & $\begin{array}{l}\text { Uče- } \\
\text { nec } 1\end{array}$ & $\begin{array}{l}\text { Uče- } \\
\text { nec } 2\end{array}$ & $\begin{array}{l}\text { Uče- } \\
\text { nec } 3\end{array}$ & $\begin{array}{l}\text { Uče- } \\
\text { nec } 4\end{array}$ & $\begin{array}{l}\text { Uče- } \\
\text { nec } 5\end{array}$ & $\begin{array}{l}\text { Uče- } \\
\text { nec } 6\end{array}$ & $\begin{array}{l}\text { Uče- } \\
\text { nec } 7\end{array}$ & $\begin{array}{l}\text { Uče- } \\
\text { nec } \\
8\end{array}$ & $\begin{array}{l}\text { Uče- } \\
\text { nec } \\
9\end{array}$ & $\begin{array}{l}\text { Števi- } \\
\text { lo PRA- } \\
\text { VILNO } \\
\text { rešenih }\end{array}$ & $\begin{array}{c}\% \\
\text { Slabših } \\
\text { bralcev }\end{array}$ \\
\hline 100 & $24-25$ & & \# & & & & & & & & $19-20$ & 100 \\
\hline 95 & 21-23 & & & $\# 0$ & \# & & & & & $\# 0$ & $16-18$ & 95 \\
\hline 90 & $19-20$ & & & & & & & & & & 15 & 90 \\
\hline 85 & $17-18$ & & 0 & & & & & & & & 14 & 85 \\
\hline 80 & 16 & & & & 0 & & & & & & 13 & 80 \\
\hline 75 & 15 & & & & & & & & & & 12 & 75 \\
\hline 70 & & & & & & 0 & & & & & 11 & 70 \\
\hline 65 & 14 & & & & & & & & & & & 65 \\
\hline 60 & 13 & & & & & & \# & \# & \# & & 10 & 60 \\
\hline 55 & 12 & & & & & & & & & & & 55 \\
\hline 50 & 11 & & & & & & & & & & 9 & 50 \\
\hline 45 & & & & & & & & & & & 8 & 45 \\
\hline 40 & 10 & & & & & & & & & & & 40 \\
\hline 35 & 9 & & & & & & & & 0 & & 7 & 35 \\
\hline 30 & 8 & & & & & & & & & & & 30 \\
\hline 25 & 7 & \# & & & & & & 0 & & & 6 & 25 \\
\hline 20 & 6 & & & & & & & & & & & 20 \\
\hline 15 & 5 & & & & & & & & & & 5 & 15 \\
\hline 10 & $2-4$ & & & & & \# & & & & & 4 & 10 \\
\hline 5 & 1 & 0 & & & & & 0 & & & & 3 & 5 \\
\hline 0 & 0 & & & & & & & & & & $0-2$ & 0 \\
\hline
\end{tabular}

Tabela 48 prikazuje rezultate Bralnega testa 9 učencev istega razreda, izbranih je nekaj naključnih učencev iz naključnega šolskega leta. Simbola \# in $o$ na grafičnem prikazu označujeta, koliko nalog je posamezen učenec pravilno rešil na posameznem podtestu. Iz Tabele 48 je razvidno, da imata Učenca 5 in 6 veliko razdaljo med simboloma na grafičnem prikazu - to pomeni, da je prevelika razlika pri rezultatu iz Hitrosti razumevanja in Stopnje razumevanja. To lahko kaže na težave pri branju - branje je prehitro, razumevanje besedišča pa slabše.

V splošnem opažam, da učenci niso vajeni, da se pri reševanju nalog meri čas. Zato bi bilo smiselno $\mathrm{v}$ drugi polovici 3. razreda načrtno več vaditi nalog z merjenjem časa. 
V šolskem letu 2019/20 se je v vsakem oddelku po 1 učenec skušal "prebiti« čez vse naloge. To se je v preteklih letih le redko dogajalo. Učence vedno znova pred začetkom testiranja motiviram, da test ni za oceno, a naj se vseeno potrudijo. Povem jim, da mogoče pa ravno njim uspe rešiti vsem 25 oz. 20 nalog.

Veliko nam pomeni tudi rezultat učencev posameznega oddelka (celotnega), saj vidimo, da so velike razlike med njimi. Ko sestavljamo oddelke za 4. razred, razporedimo učence tako, da so nadpovprečni in podpovprečni čim bolj enakomerno porazdeljeni med vse 3 oddelke, da se preseže neenakost in bodo njihovi učni dosežki ob koncu šolskega leta približno enaki v vseh oddelkih.

\section{Zaključek}

Učitelji 3.-5. r. si lahko pri razvijanju bralnih strategij pomagamo s priročnikom Sonje Pečjak in Mire Kramarič: Bralne strategije. Učenci so v kompletu z delovnimi zvezki za 3. razred prejeli brezplačno knjižico Bralne strategije, Primeri besedil za 3. razred. Učiteljem je priročnik v veliko oporo in pomoč; knjižica z besedili pa je namenjena diferenciaciji pouka; sposobnejši učenci jo rešujejo tudi pri urah dodatnega pouka.

Šolski projektni tim je znotraj projekta BUS letno pripravil veliko medsebojnih hospitacij - učitelji smo prehajali iz razredne na predmetno stopnjo in obratno. Pripravljali/analizirali smo učne ure, na katerih so hospitirali tudi novomeški svetovalci iz Zavoda za šolstvo. Mislim, da je vse to pripomoglo, da se je na OŠ Loka Črnomelj spremenila miselnost celotnega kolektiva, da smo za bralno razumevanje učencev odgovorni vsi.

$\mathrm{Na}$ OŠ Loka Črnomelj smo na dobri poti do še boljših rezultatov Bralnega testa, ki je vsakoletni del Samoevalvacijskega poročila našega zavoda. Pomembno se mi zdi predvsem to, da pravočasno prepoznamo individualne zmožnosti učencev, še posebej tistih, ki imajo nižje bralne zmožnosti.

\section{Literatura}

Bryant, Peter, Nunes, Terezinha. »Introduction."V Handbook of Children's Literacy, 3-10. Urednika T. Nunes in P. Bryant,. Dordrecht: Kluwer Academic Publishers, 2004.

Goswami, Usha, Bryant, Peter. Phonological skills and learning to read. London: Erlbaum, 1990. 
Magajna, Lidija, Gradišar, Ana, Mesarič, Vid, Pečjak, Sonja, Pust, Nataša. Strategije preprečevanja šolske neuspešnosti in spodbujanja kvalitete učenja: interpretativni pristop (kognicija, metakognicija in motivacija). Zaključno poročilo o realizaciji projekta (1997-1999). Ljubljana: Svetovalni center za otroke, mladostnike in starše. Republika Slovenija Ministrstvo za šolstvo in šport: Urad RS za šolstvo, 1999.

Magajna, Lidija. Učenci z učnimi težavami. Prepoznavanje in diagnostično ocenjevanje. Ljubljana: Pedagoška fakulteta, 2011.

MIZŠ. Učni načrt za slovenščino. Ljubljana: MIZŠ, 2018. https://www.gov.si/assets/ministrstva/MIZS/Dokumenti/Osnovna-sola/Ucni-nacrti/obvezni/ UN_slovenscina.pdf. (25. 7. 2020)

Pečjak, Sonja, Magajna, Lidija, Podlesek, Anja. Bralni test. Ljubljana: Filozofska fakulteta, 2012.

Pečjak, Sonja, Magajna, Lidija, Podlesek, Anja. Ocenjevalna shema bralnih zmožnosti učencev 1.-3. razreda OSBZ. Univerza v Ljubljani, Filozofska fakulteta, 2012.

Pečjak, Sonja. Psihološki vidiki bralne pismenosti. Od teorije k praksi. Ljubljana: Znanstveni institut Filozofske fakultete v Ljubljani, 2010.

Pečjak, Sonja., Kramarič, Mira. Bralne strategije. Priročnik za učitelje 3., 4. in 5. razreda. Ljubljana: Rokus Klett, 2015.

PIRLS. Mednarodna raziskava bralne pismenosti PIRLS 2011. Ljubljana: Pedagoški inštitut, 2011.

Verhoeven, Ludo,, Snow, Catherine E. »Literacy and motivation: bridging cognitive and sociocultural viewpoints. "V Literacy and motivation: reading engagement in individuals and groups, 1- 20. Urednika Verhoeven, L. in Snow, C. E. Mahwah: LEA, 2001. 